\title{
Comparison of Effectiveness of Raw Okra (Abelmoschus esculentus L) and Raw Sugarcane (Saccharum officinarum) Wastes as Bioadsorbent of Heavy Metal in Aqueous Systems
}

\author{
Olabanji I. O. ${ }^{1} \&$ Oluyemi E. ${ }^{2}$ \\ ${ }^{1}$ Department of Chemistry, Obafemi Awolowo University, Ile-Ife, Nigeria \\ Correspondence: Olabanji I. O., Department of Chemistry, Obafemi Awolowo University, Ile-Ife, Nigeria. Tel: \\ 234-80-3462-0878. E-mail: ioolabanji@yahoo.com
}

Received: August 13, 2014 Accepted: August 25, 2014 Online Published: December 2, 2014

doi:10.5539/ep.v4n1p1 URL: http://dx.doi.org/10.5539/ep.v4n1p1

\begin{abstract}
Adsorption process had been effective in condensing and concentrating metal ions from aqueous phase to the surface of adsorbent, it is a well established technology that employed the use of synthetic adsorbent which are usually scarce and expensive in waste water treatment. Hence, there is a need to develop new adsorbent which are readily available at low cost to remove metal contaminants in aqueous system. In this work, raw sugarcane waste and raw okra waste which are agricultural by-products were used as adsorbent in the adsorption of Fe(III) $\mathrm{Cd}$ (II), $\mathrm{Pb}$ (II), Zn (II), Ni (II) from various aqueous solutions. Infrared spectrum of the okra and sugar cane waste were recorded to detect the functional groups that has the binding capability for the metal ion adsorption. Batch studies were performed to evaluate the adsorption process and its was found that the okra waste was able to adsorb $5.05 \%$ of $\mathrm{Fe}(\mathrm{III})$,), $44.95 \%$ of $\mathrm{Cd}$ (II), ), $65.10 \%$ of $\mathrm{Pb}$ (II), $38.78 \%$ of $\mathrm{Zn}$ (II), $57.80 \%$ of Ni(II), while the sugarcane waste was able to adsorb $3.61 \%$ of Fe (III), 35.06\% of Cd (II), $43.50 \%$ of $\mathrm{Pb}$ (II), , $24.45 \%$ of $\mathrm{Zn}$ (II), $35.31 \%$ of $\mathrm{Ni}(\mathrm{II})$. This work proved that raw okra waste was more effective adsorbent material than raw sugarcane waste for the removal of heavy metals from aqueous systems. The Freundlich adsorption model described well the sorption equilibrium of the metal ions however research study have shown that modified form of okra waste was an excellent adsorbent, there is possibility of modifying the raw sugar cane waste for better performance since it has potential of removing heavy metals in waste water.
\end{abstract}

Keywords: sugar cane waste, okra waste, infra red spectral, waste water

\section{Introduction}

The increase in population coupled with increasing technology led to increase in industrial growth and generation of heavy metals in industries, such as smelting, electroplating, lead-batteries cycling, metallurgy and many more (Igbinosa \& Okoh, 2009; Shah et al., 2009; Vohra, 2010). As a result of these, stricter discharge regulations that could lowered permissible contaminant levels in waste streams had been enacted because of decrease in potable water, water resources and huge cost of treatment of waste water (Gupta et al., 2000; ESCWA, 2003). Un-treated industrial wastewater contains larger quantities of heavy metals, causing pollution which is a significant environmental problem. The metal ions are mobile in water bodies, they are nondegradable in nature, they are also toxic to aquatic organisms and accumulates throughout the food chain leading to both ecological and health problems that call for concern. These and many other reasons have made metal pollution a topic of global interest (Akar et al., 2005; Mohsen, 2007). Biosorption is a physico-chemical process of binding of chemical species to biopolymers. The use of biological materials such as okra waste which is structurally made of $\alpha$-cellulose, protein lignin and mineral elements in small percentage had been carried out by researchers for reducing the metal load from both synthetic and industrial waste water (Mohsem, 2007; Al-Barak \& El-Said, 2010; Adnan, 2012), these researchers had established the potential use of raw and modified okra waste for the removal of $\mathrm{Pb}, \mathrm{Cd}, \mathrm{Fe}$ and other metals. Lignocellulosic wastes such as sugar waste having $40 \% \mathrm{wt}$ of cellulose, $27 \%$ wt of hemicellulose and 10\%wt of lignin (Nigam, 2009) could also serve the same purpose because of the presence of the $-\mathrm{OH}$ bond of the cellulose.

This study aimed at comparing the effectiveness of the removal of heavy metals by the raw okra waste with the raw sugar cane waste which could serve as basis for modification for the sugar cane waste for effective use as 
biopolymer adsorbent and determine the best adsorption isotherm for the equilibrium processes.

\section{Material Studied}

\subsection{Sample Collection and Sample Preparation}

Dry okra pods were collected from a farmer and the sugar cane was bought from the market within Ile- Ife metropolis. The glass wares were thoroughly cleansed with liquid soap and rinsed severally with distilled water and oven dry at $60^{\circ} \mathrm{C}$ overnight before use. The metal ion solutions of $\mathrm{Pb}, \mathrm{Ni}, \mathrm{Cd}, \mathrm{Fe}, \mathrm{Zn}$ were prepared from analytical grade $(\mathrm{BDH})$ of $\mathrm{Pb}\left(\mathrm{NO}_{3}\right)_{2}, \mathrm{CdSO}_{4}, \mathrm{ZnCl}_{2}, \mathrm{FeCl}_{3}, \mathrm{NiCl}_{2}$ salts respectively using de-ionized water. Okra and sugarcane powder were obtained from their shaft. The seed of the dry okra pod collected were removed, and the shaft washed with distilled water, drained and oven dry at $60^{\circ} \mathrm{C}$ to constant weight, the sugar cane coat was removed, cut into bit and crush by grinder, packed in a white cloth bag made purposely for it and squeezed. The pulp was soaked in water severally to remove the sugar content and then oven dry at $60^{\circ} \mathrm{C}$ to constant weight. This was made into powdery form by an electric mixer and sieved into particle sizes of about $0.5-4 \mathrm{~mm}$. The infrared (IR) absorption spectrum were used to investigate the chemical structure of okra and sugarcane waste both before (figure 1and 2) and after use (Figure 3 and 4).

An infrared spectrum (IR) of okra and sugar cane waste were obtained using Thermo ScientificNicolet iS5 FT-IR spectrometer (Madison, WI USA). The infrared spectrum of the solid substance was recorded in the region of $400-4000 \mathrm{~cm}^{-1}$ using $\mathrm{KBr}$ technique. The observed frequencies were assigned to the peaks.

\subsection{Experimental}

The sorption of cadmium (II), Zinc (II), lead (II), Nickel (II) were studied and carried out using agitation method to bring about the adsorption. Solution of $\mathrm{Cd}^{2+}$ ions $\left(200 \mathrm{mgL}^{-1}\right), \mathrm{Zn}^{2+}$ ions $\left(200 \mathrm{mLL}^{-1}\right), \mathrm{Pb}^{2+}$ ions $\left(200 \mathrm{mgL}^{-1}\right)$, $\mathrm{Ni}^{2+}$ ions $\left(200 \mathrm{mgL}^{-1}\right)$ were prepared from the pure salt each metal ion using deionized water. These were subjected to AAS analysis for confirmation of the concentration before use as synthetic waste water. From these stock solutions, serial dilution were carried out as $(100,50,30,10$ and 5) $\mathrm{mg} / \mathrm{L}$ for calibration of the equipment for metal analysis at the most sensitive wavelength.

Thirty millimeter of $100 \mathrm{mg} / \mathrm{L}$ of each salt solution (synthetic waste water) were pipette into five polyethylene bottles and two other bottles, one containing the same volume synthetic waste water and the second containing equal volume other de-ionized water (they served as blanks for control measure). Okra waste powder of $0.5 \mathrm{~g}$ was weighed into the five sample bottles for each salt separately. Using a Stuart Scientific flask shaker, uniform agitation of the samples were carried out for each salt solution and the blanks at a constant speed $500 \mathrm{rev} / \mathrm{min}$ at varying times of $30 \mathrm{~min}, 60 \mathrm{~min}, 90 \mathrm{~min}, 120 \mathrm{~min}$ and $150 \mathrm{~min}$ (five experimental set- up). The agitated samples were filtered and made up to $100 \mathrm{~mL}$ and the concentration of $\mathrm{Cd}^{2+}, \mathrm{Ni}^{2+}, \mathrm{Zn}^{2+}, \mathrm{pb}^{2+}$ ions were determined by atomic absorption spectrophotometer (Buck model 205). The same procedure was carried out with sugar cane waste powder.

The adsorption percentage was determined as:

$$
\eta=\frac{C_{0}-C_{e}}{C_{0}} \times 100
$$

$\eta$ is the adsorption percentage of cation and $\mathrm{C}_{0}$ and $\mathrm{C}_{\mathrm{e}}$ are the initial and equilibrium concentration of cations respectively $\left(\mathrm{mgL}^{-1}\right)$

\subsection{Quantification of the Heavy Metals}

At the expiration of the agitation time, the metal concentration were determined in the filtrate, these values were subtracted from the initial concentration to determine the concentration of the adsorbed metal ions. The actual concentration were found using the dilution factor ratio;

$\mathrm{M}_{\mathrm{C}}=\frac{\mathrm{CC} \mathrm{x} \text { final volume of the filtrate }}{\text { Mass of the adsorbent used }}$

$\mathrm{M}_{\mathrm{C}}=$ Actual Concentration Adsorbed

$\mathrm{CC}=$ Calculated Concentration

\subsection{Statistical Analysis}

Microsoft office Excel was used to process the chart and correlation table at $95 \%$ confidence interval. 


\subsection{Quality Control Measures}

Quality control used included determination of heavy metal concentration in the de- ionized water and waste water used in agitation to rule out errors. Calibration of the Atomic Absorption Spectrphotometer by the working solution of $\left(100,50,30,10\right.$ and 5) $\mathrm{mg} / \mathrm{L}$ with $\mathrm{r}^{2}$ value between $0.988-0.999$, which were adjudge good (Miller and Miller 2000). Ensuring that the salts of the metal ions were Analytical grade and the use of de- ionize water to ensure that the measured concentrations were from the synthetic waste water.

\section{Results and Discussion}

Okra waste is structurally made of $\alpha$ - cellulose and protein (Mohsem, 2007; Adnan, 2012), the infra red analysis of the raw okra waste (Figure 1) showed that amino, hydroxyl and carboxyl $(\mathrm{N}-\mathrm{H}, \mathrm{OH}, \mathrm{C}=\mathrm{O}$, and $\mathrm{C}-\mathrm{O}-\mathrm{C}$ ) depicting the functional groups of its constituents. The adsorption of metal ion on the wastes may involve interactions of the metals or coordination of the metals to functional groups present in natural proteins, lipids, and carbohydrates of the wastes (Kumar, 2006; Drake et al., 1996). Lone pair of electrons on oxygen and nitrogen atoms supplies electron to the electron deficient positively charged metals which made adsorption by okra waste possible, hence positively charged metals of $\mathrm{Cd}$ (II), $\mathrm{Pb}$ (II), $\mathrm{Zn}$ (II), Ni (II) could be removed. The sugar cane waste is made up cellulose, hemicellulose, lignin, and other impurities (Nigam, 2009) and functional groups such as $\mathrm{OH}, \mathrm{C}=\mathrm{O}, \mathrm{C}-\mathrm{O}$ and $\mathrm{M}-\mathrm{O}$ were found (Figure 2). The shift in bands after the use of these waste materials showed that there was an adsorption in the course of agitation on the surface or charged site of the functional groups (Figures 3 and 4).

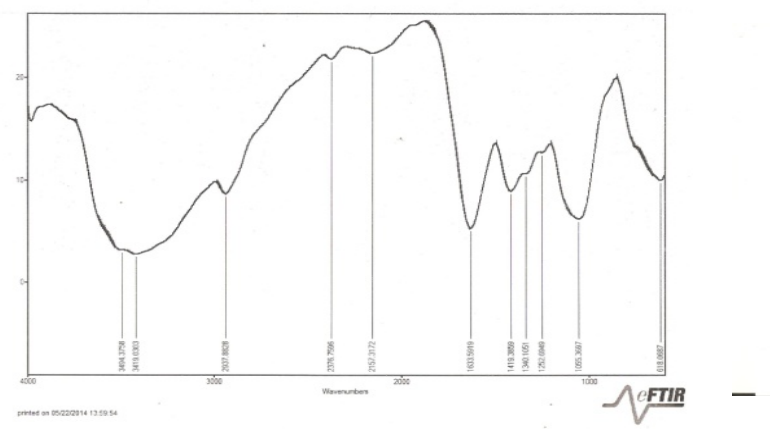

Figure 1. Infra Red spectral of raw okra waste

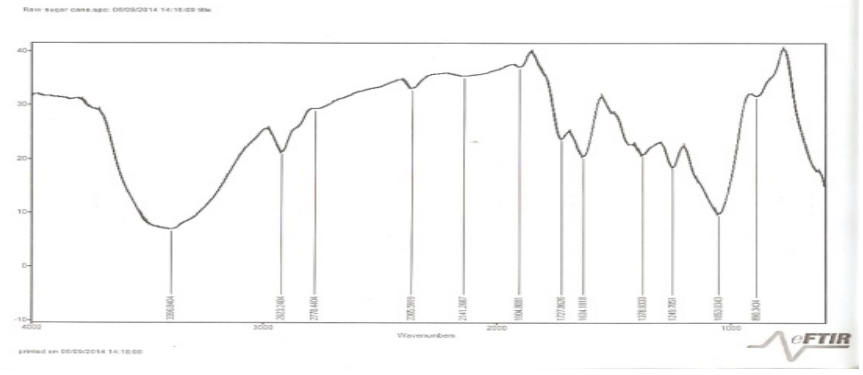

Figure 2. Infra Red spectral of raw sugar cane waste

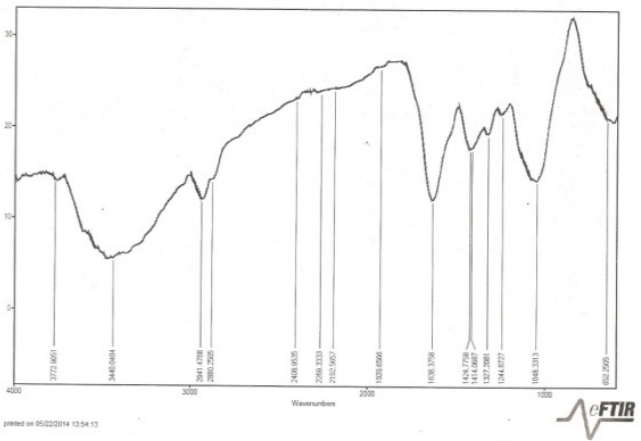

Figure 3. Infra Red spectral of used okra waste

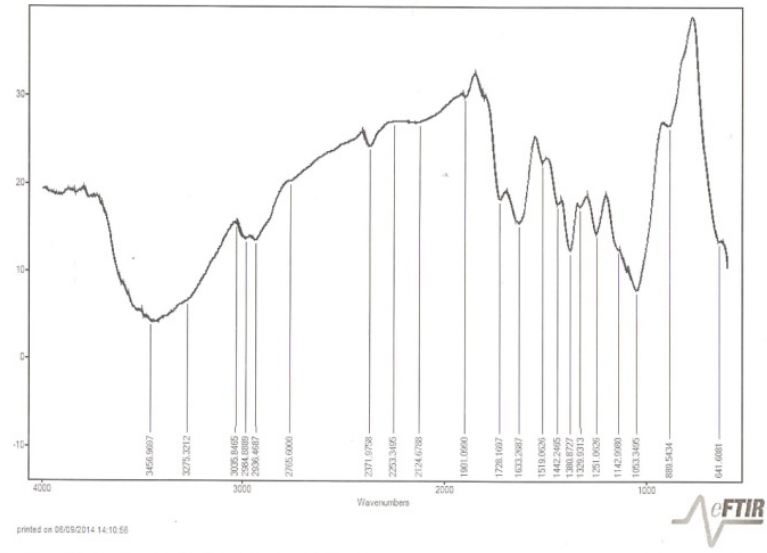

Figure 4. Infra Red spectral of used sugar cane waste

The shift in bands were more pronounce in used okra waste than in the used sugar cane waste as shown (Table 1). 
Although, there were no significant band shift in the functional groups of sugar cane waste except in the $\mathrm{OH}$ group and $\mathrm{C}=\mathrm{O}$, the reduction in the intensities of the peaks showed that adsorption took place (Figure 2 and 4 ), the spectrum looks similar because of the similar molecular composition of the waste (cellulose).

Tables1. Showing band shift of the functional groups in the Raw Sugar Cane and Raw okra Wastes before and after use

\begin{tabular}{|c|c|c|c|c|c|c|c|}
\hline \multicolumn{4}{|c|}{ Raw Sugar cane Waste } & \multicolumn{4}{|c|}{ Raw Okra Waste } \\
\hline \multicolumn{2}{|c|}{ Before use } & \multicolumn{2}{|c|}{ After use } & \multicolumn{2}{|c|}{ Before use } & \multicolumn{2}{|c|}{ After use } \\
\hline $\begin{array}{c}\text { Wave } \\
\text { numbers } / \mathrm{cm}^{-1}\end{array}$ & $\begin{array}{c}\text { Functional } \\
\text { Group }\end{array}$ & $\begin{array}{c}\text { Wave } \\
\text { numbers } / \mathrm{cm}^{-1}\end{array}$ & $\begin{array}{c}\text { Functional } \\
\text { Group }\end{array}$ & $\begin{array}{c}\text { Wave } \\
\text { numbers } / \mathrm{cm}^{-1}\end{array}$ & $\begin{array}{c}\text { Functional } \\
\text { Group }\end{array}$ & $\begin{array}{c}\text { Wave } \\
\text { numbers } / \mathrm{cm}^{-1}\end{array}$ & $\begin{array}{c}\text { Functional } \\
\text { Group }\end{array}$ \\
\hline 3396 & $\mathrm{OH}$ & 3456 & $\mathrm{OH}$ & 3494 & $\mathrm{OH}$ & 3772 & $\mathrm{OH}$ \\
\hline 1633 & $\mathrm{C}=\mathrm{O}$ & 1634 & $\mathrm{C}=\mathrm{O}$ & 3419 & $\mathrm{~N}-\mathrm{H}$ & 3440 & $\mathrm{~N}-\mathrm{H}$ \\
\hline 1053 & $\mathrm{C}-\mathrm{O}$ & 1053 & $\mathrm{C}-\mathrm{O}$ & 1633 & $\mathrm{C}=\mathrm{O}$ & 1638 & $\mathrm{C}=\mathrm{O}$ \\
\hline \multirow[t]{3}{*}{641} & $\mathrm{M}-\mathrm{O}$ & 641 & $\mathrm{M}-\mathrm{O}$ & 1252 & $\mathrm{C}-\mathrm{O}-\mathrm{C}$ & 1244 & $\mathrm{C}-\mathrm{O}-\mathrm{C}$ \\
\hline & & & & 1055 & $\mathrm{C}-\mathrm{O}$ & 1018 & $\mathrm{C}-\mathrm{O}$ \\
\hline & & & & 618 & $\mathrm{M}-\mathrm{O}$ & 652 & $\mathrm{M}-\mathrm{O}$ \\
\hline
\end{tabular}

The effect of time over the concentration of adsorbed metal showed that raw okra waste adsorbed the metal ion more than the raw sugar cane, this may be as a result of the number of the functional groups that were found in the IR spectral of the okra waste. The inclusion of the N-H group provided a better charged sites for metal removal in the okra waste than in the sugar cane waste (Figure 5). There was a steady increase in the concentration of metals adsorbed and effective adsorption took place at 120 minutes after which there was no significant increase and equilibrium was achieved. The efficiency of the removal of the heavy metal in relation to time for both waste followed the same order $\mathrm{Pb}>\mathrm{Ni}>\mathrm{Cd}>\mathrm{Zn}$, may be because they are agricultural waste having (cellulose and lignin) in common.

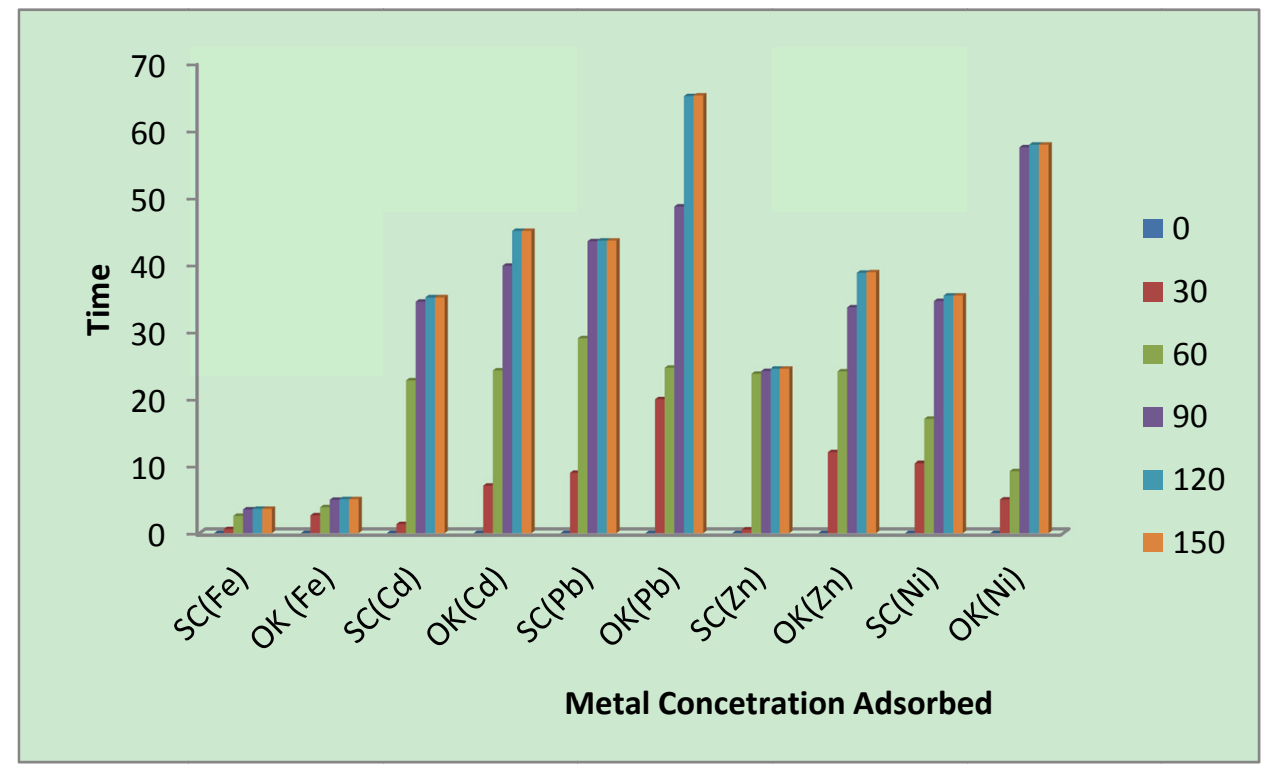

Figure 5. Concentration of metal ion removed with time

The performance of raw okra was $1.5 \pm 0.2$ (Table 2) better than that of raw sugar cane in terms of percentage removal. Okra waste adsorbed $5.05 \%$ of $\mathrm{Fe}(\mathrm{III}), 44.95 \%$ of $\mathrm{Cd}$ (II), $65.10 \%$ of $\mathrm{Pb}$ (II), $38.78 \%$ of $\mathrm{Zn}$ (II), $57.80 \%$ of $\mathrm{Ni}(\mathrm{II})$, while the sugar cane waste adsorbed $3.61 \%$ of Fe (III), 35.06 \% of Cd (II), 43.50\% of Pb (II), $24.45 \%$ of $\mathrm{Zn}$ (II), 35.31\% of $\mathrm{Ni}$ (II). From the order of effective removal, these wastes could be used to remove $\mathrm{Pb}$, Ni and Cd effectively if modified. Mohsen (2007) found modified okra waste to remove $99 \% \mathrm{~Pb}^{2+}$ 
Table 2. Ratio of percentage removal of Okra waste and Sugar cane waste

\begin{tabular}{llll}
\hline Metal ion & Okra Waste \% Removal & Sugar cane \% Removal & Ratio of Effectiveness \\
\hline $\mathrm{Pb}^{2+}$ & 65.1 & 43.5 & 1.5 \\
$\mathrm{Ni}^{2+}$ & 57.8 & 35.31 & 1.6 \\
$\mathrm{Cd}^{2+}$ & 44.95 & 35.06 & 1.3 \\
$\mathrm{Zn}^{2+}$ & 38.78 & 24.45 & 1.6 \\
$\mathrm{Fe}^{3+}$ & 5.05 & 3.61 & 1.4 \\
\hline
\end{tabular}

\subsection{Adsorption Isotherm}

The nature of the adsorption process described the equilibrium between the concentration of adsorbate in solution (mass/ volume) and its sorbed concentration (mass adsorbate/mass adsorbent). Langmuir isotherm assumes that a single adsorbate binds to a single site on the adsorbent and that all surface sites on the adsorbent have the same affinity for the adsorbent. The Langmuir equation

$\mathrm{C}_{\mathrm{e}} / \mathrm{Q}_{\mathrm{e}}=\mathrm{C}_{\mathrm{e}} 1 / \mathrm{Q}_{\mathrm{m}}+1 / \mathrm{K}_{\mathrm{a}} \mathrm{Q}_{\mathrm{m}}$

where $\mathrm{C}_{\mathrm{e}}=$ the equilibrium concentration of metal ion $(\mathrm{mg} / \mathrm{L})$

$\mathrm{Q}_{\mathrm{e}}=$ the amount of metal ion sorbed at equilibrium $(\mathrm{mg} / \mathrm{g})$

$\mathrm{Q}_{\mathrm{m}}=$ the maximum adsorption capacity

$\mathrm{K}_{\mathrm{a}}=$ the coefficient related to the affinity between the adsorbent and the metal ion and also related to energy of adsorption.

A plot of $C_{e} / Q_{e}$ against $C_{e}$ gave a straight line. The result of the kinetic study of the effect of concentration change with time showed a good linearity with regression coefficient $\left(\mathrm{r}^{2}\right)$ value above 0.90 (table 3 ) for the Langmuir isotherm except $\mathrm{Ni}$ in Okra waste and Cd of both wastes. $\mathrm{Q}_{\mathrm{m}}$ and $\mathrm{K}_{\mathrm{a}}$ were evaluated (Figure 6 and 7 for sugar cane and okra adsorbent graphs for $\mathrm{Pb}$ ) by comparing the linear regression equation with the linear Langmuir equation.

The values of qm were greater than 1 in $\mathrm{Pb}$ and $\mathrm{Ni}$ for sugar cane waste and also greater than 1 in all the metal ions except $\mathrm{Fe}$ in okra waste indicated that the adsorbent would be effective when the initial concentrations metal ions being removed were higher (Oke et al., 2008; Malakootian et al., 2009; Oluyemi et al., 2012). 
Table 3. Showing Langmuir Isotherm terms

\begin{tabular}{|c|c|c|c|c|c|c|c|c|c|c|}
\hline \multirow[t]{3}{*}{ Time } & \multicolumn{10}{|c|}{ Langmuir Isotherm of Sugar Cane Waste } \\
\hline & \multicolumn{2}{|l|}{$\mathrm{Cd}$} & \multicolumn{2}{|l|}{$\mathrm{Pb}$} & \multicolumn{2}{|l|}{$\mathrm{Fe}$} & \multicolumn{2}{|l|}{$\mathrm{Ni}$} & \multicolumn{2}{|l|}{$\mathrm{Zn}$} \\
\hline & $\mathrm{Ce} / \mathrm{Qe}$ & $\mathrm{Ce}$ & $\mathrm{Ce} / \mathrm{Qe}$ & $\mathrm{Ce}$ & $\mathrm{Ce} / \mathrm{Qe}$ & $\mathrm{Ce}$ & $\mathrm{Ce} / \mathrm{Qe}$ & $\mathrm{Ce}$ & $\mathrm{Ce} / \mathrm{Qe}$ & $\mathrm{Ce}$ \\
\hline 30 & 73.0741 & 197.30 & 10.1732 & 182.1 & 180.8182 & 198.90 & 8.6618 & 179.3 & 180.8182 & 198.90 \\
\hline 60 & 3.4248 & 154.80 & 2.4483 & 142.0 & 37.6847 & 194.83 & 4.9172 & 166.20 & 3.2194 & 152.60 \\
\hline 90 & 1.9028 & 131.10 & 1.3041 & 113.2 & 27.4091 & 192.96 & 1.8944 & 130.90 & 3.1494 & 151.80 \\
\hline 120 & 1.8531 & 129.90 & 1.2989 & 113.0 & 26.6625 & 192.77 & 1.8329 & 129.40 & 3.0899 & 151.10 \\
\hline 150 & 1.8523 & 129.88 & 1.2989 & 113.0 & 26.6625 & 192.77 & 1.8329 & 129.23 & 3.0899 & 151.10 \\
\hline $\mathrm{R}^{2}$ & 0.8819 & & 0.9144 & & 0.9307 & & 0.9335 & & 0.9992 & \\
\hline $\mathrm{Q}_{\mathrm{m}}$ & 0.9842 & & 8.1967 & & 0.0403 & & 8.2305 & & 0.26615 & \\
\hline \multirow[t]{4}{*}{$\mathrm{K}_{\mathrm{a}}$} & \multicolumn{2}{|c|}{$-7.5496 \times 10^{-3}$} & \multicolumn{2}{|c|}{$-9.471 \times 10^{-3}$} & \multicolumn{2}{|c|}{$-5.208 \times 10^{-3}$} & \multicolumn{2}{|c|}{$-8.6519 \times 10^{-3}$} & \multicolumn{2}{|c|}{$-6.631 \times 10^{-3}$} \\
\hline & \multicolumn{10}{|c|}{ Langmuir Isotherm of Okra Waste } \\
\hline & \multicolumn{2}{|l|}{$\mathrm{Cd}$} & \multicolumn{2}{|l|}{$\mathrm{Pb}$} & \multicolumn{2}{|l|}{$\mathrm{Fe}$} & \multicolumn{2}{|l|}{$\mathrm{Ni}$} & \multicolumn{2}{|l|}{$\mathrm{Zn}$} \\
\hline & $\mathrm{Ce} / \mathrm{Qe}$ & $\mathrm{Ce}$ & $\mathrm{Ce} / \mathrm{Qe}$ & $\mathrm{Ce}$ & $\mathrm{Ce} / \mathrm{Qe}$ & $\mathrm{Ce}$ & $\mathrm{Ce} / \mathrm{Qe}$ & $\mathrm{Ce}$ & $\mathrm{Ce} / \mathrm{Qe}$ & $\mathrm{Ce}$ \\
\hline 30 & 13.1844 & 185.90 & 4.0505 & 160.40 & 36.7359 & 194.70 & 19.000 & 190.00 & 7.3682 & 176.10 \\
\hline 60 & 3.1322 & 151.60 & 3.0650 & 150.80 & 24.9740 & 192.30 & 9.8370 & 181.60 & 3.1580 & 151.90 \\
\hline 90 & 1.5157 & 120.50 & 1.0534 & 102.60 & 19.2020 & 190.10 & 0.7422 & 85.20 & 1.9762 & 132.80 \\
\hline 120 & 1.2247 & 110.10 & 0.5385 & 70.00 & 18.8020 & 189.90 & 0.7316 & 84.50 & 1.5840 & 122.60 \\
\hline 150 & 1.2247 & 110.10 & 0.5361 & 69.80 & 18.8020 & 189.90 & 0.7316 & 84.50 & 1.5787 & 122.44 \\
\hline $\mathrm{R}^{2}$ & 0.8546 & & 0.9494 & & 0.9762 & & 0.8796 & & 0.9198 & \\
\hline $\mathrm{Q}_{\mathrm{m}}$ & 6.8775 & & 27.473 & & 0.2765 & & 7.2411 & & 9.7371 & \\
\hline $\mathrm{K}_{\mathrm{a}}$ & $-9.285 \times$ & & $-1.673 \times$ & & $-5.410 \times 10$ & & $-1.25 \mathrm{X}$ & & $-9.036 \times 10$ & \\
\hline
\end{tabular}
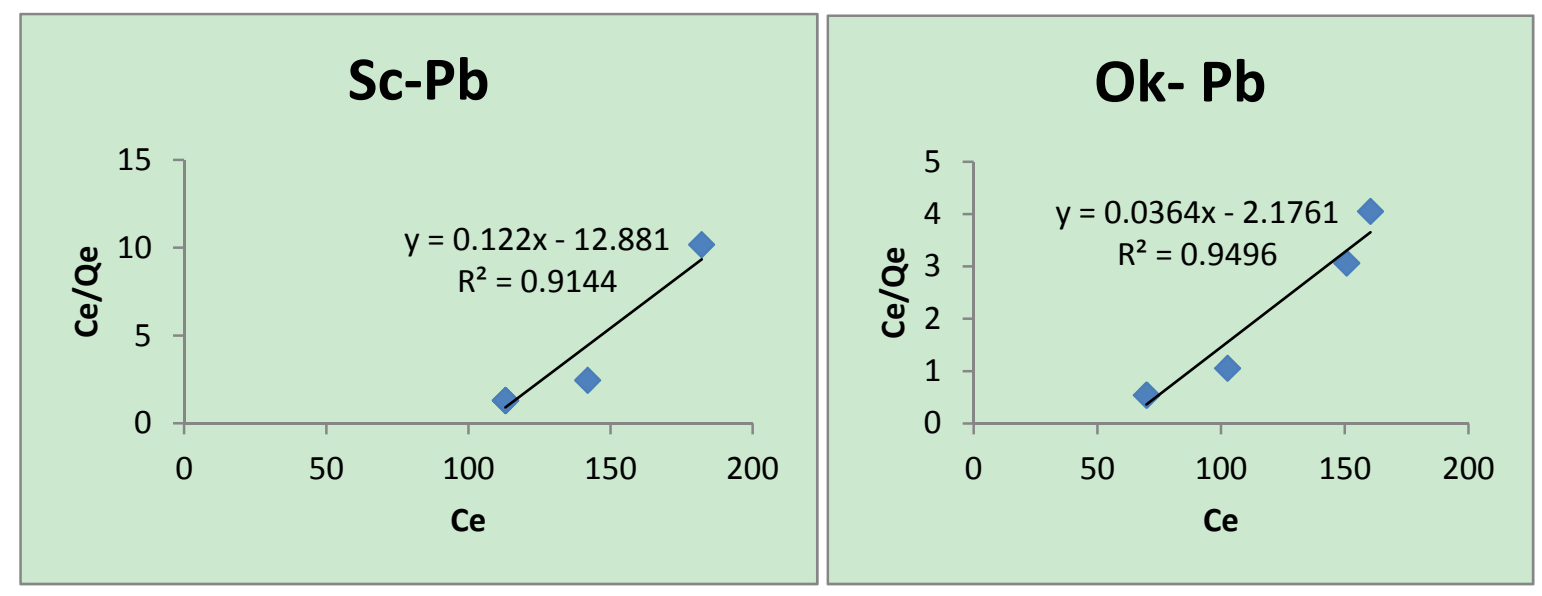

Figure 6 and 7. Langmuir adsorption graph for Pb using Sugar cane and okra adsorbents

The freundlich model, an empirical equation used to describe heterogeneous adsorption systems can be represented as

$\log Q_{\mathrm{e}}=1 / \mathrm{n} \log \mathrm{C}_{\mathrm{e}}+\log \mathrm{K}_{\mathrm{f}}$

where $\mathrm{C}_{\mathrm{e}}$ and $\mathrm{Q}_{\mathrm{m}}$ as described above and $\mathrm{K}_{\mathrm{f}}$ and $\mathrm{n}$ are the Freundlich constant related to maximum sorption capacity and the heterogeneous factor respectively. $\mathrm{K}_{\mathrm{f}}$ and $\mathrm{n}$ calculated by equating the Freundlich equation to the linear regression equation. 
Table 4. Showing Freundlich Isotherm terms

\begin{tabular}{|c|c|c|c|c|c|c|c|c|c|c|}
\hline \multirow[t]{3}{*}{ Time } & \multicolumn{10}{|c|}{ Freundlish Isotherm of Sugar Cane Waste } \\
\hline & \multicolumn{2}{|c|}{$\mathrm{Cd}$} & \multicolumn{2}{|l|}{$\mathrm{Pb}$} & \multicolumn{2}{|l|}{$\mathrm{Fe}$} & \multicolumn{2}{|l|}{$\mathrm{Ni}$} & \multicolumn{2}{|l|}{$\mathrm{Zn}$} \\
\hline & $\log \mathrm{Ce}$ & Log Qe & $\log \mathrm{Ce}$ & Log Qe & $\log \mathrm{Ce}$ & Log Qe & $\log \mathrm{Ce}$ & Log Qe & $\log \mathrm{Ce}$ & Log Qe \\
\hline 30 & 2.2951 & 0.4314 & 2.2603 & 1.2529 & 2.2986 & 0.0414 & 2.2516 & 1.3160 & 2.2986 & 0.04 \\
\hline 60 & 2.1898 & 1.6551 & 2.1523 & 1.7634 & 2.2897 & 0.7135 & 2.2206 & 1.5289 & 2.1836 & 1.6758 \\
\hline 90 & 2.1176 & 1.8382 & 2.0538 & 1.9385 & 2.2855 & 0.8476 & 2.1169 & 1.8395 & 2.1813 & 1.6830 \\
\hline 120 & 2.1136 & 1.8457 & 2.0531 & 1.9395 & 2.2850 & 0.8591 & 2.1119 & 1.8488 & 2.1793 & 1.6893 \\
\hline 150 & 2.1135 & 1.8458 & 2.0531 & 1.9395 & 2.2850 & 0.8591 & 2.1119 & 1.8489 & 2.1793 & 1.6893 \\
\hline $\mathrm{R}^{2}$ & 0.9183 & & 0.9502 & & 0.9715 & & 0.9769 & & 0.9993 & \\
\hline $\mathrm{n}$ & -0.134 & & -0.3179 & & -0.0167 & & -0.2820 & & -0.07172 & \\
\hline \multirow[t]{4}{*}{$\mathrm{K}_{\mathrm{f}}$} & \multicolumn{2}{|c|}{$4.62 \times 10^{17}$} & \multicolumn{2}{|c|}{$2.6248 \times 10^{8}$} & \multicolumn{2}{|c|}{$2.351 \times 10^{3}$} & \multicolumn{2}{|c|}{$2.16 \times 10^{9}$} & \multicolumn{2}{|c|}{$1.24 \times 10^{32}$} \\
\hline & \multicolumn{10}{|c|}{ Freundlish Isotherm of Okra Waste } \\
\hline & \multicolumn{2}{|c|}{$\mathrm{Cd}$} & \multicolumn{2}{|c|}{$\mathrm{Pb}$} & \multicolumn{2}{|l|}{$\mathrm{Fe}$} & \multicolumn{2}{|l|}{$\mathrm{Ni}$} & \multicolumn{2}{|l|}{$\mathrm{Zn}$} \\
\hline & $\log \mathrm{Ce}$ & Log Qe & $\log \mathrm{Ce}$ & Log Qe & $\log \mathrm{Ce}$ & Log Qe & $\log \mathrm{Ce}$ & Log Qe & $\log \mathrm{Ce}$ & Log Qe \\
\hline 30 & 2.2693 & 1.1492 & 2.2052 & 1.5977 & 2.2894 & 0.7243 & 2.2788 & 1.000 & 2.2458 & 1.3784 \\
\hline 60 & 2.1807 & 1.6840 & 2.1784 & 1.6920 & 2.2840 & 0.8865 & 2.2591 & 1.2648 & 2.1816 & 1.6821 \\
\hline 90 & 2.0809 & 1.9004 & 2.0112 & 1.9886 & 2.2790 & 0.9956 & 1.9304 & 2.0599 & 2.1232 & 1.8274 \\
\hline 120 & 2.0418 & 1.9538 & 1.8451 & 2.1139 & 2.2785 & 1.0043 & 1.9269 & 2.0626 & 2.0885 & 1.8887 \\
\hline 150 & 2.0418 & 1.9538 & 1.8439 & 2.1146 & 2.2785 & 1.0043 & 1.929 & 2.0626 & 2.0879 & 1.8896 \\
\hline $\mathrm{R}^{2}$ & 0.9240 & & 0.9590 & & 0.9913 & & 0.9792 & & 0.9614 & \\
\hline $\mathrm{n}$ & -0.303 & & -0.73389 & & -0.0403 & & -0.3648 & & -0.3210 & \\
\hline $\mathrm{K}_{\mathrm{f}}$ & $5.4 \times 10^{8}$ & & $4.46 \times 10$ & & $4.02 \times 10$ & & $2.23 \times 10$ & & $2.61 \times 10$ & \\
\hline
\end{tabular}

The high level of $\mathrm{K}_{\mathrm{F}}$ (the binding constant) and low $\mathrm{n}$ (the exponent) values (less than zero) in all the cases treated from the Freundlich isotherm (Table 4) showed that the adsorption capacity of sugar cane and okra wastes were high and that any large change in the equilibrium concentration of the ions would not result in a remarkable change in the amount of the ions adsorbed by wastes. It is also showed that significant adsorption took place at low concentration but the increase in the amount adsorbed with concentration becomes less significant at higher concentration and vice versa (This is in agreement with the result of Oluyemi et al., 2012). The high $\mathrm{K}_{\mathrm{f}}$ values indicated the high adsorption capacity of these wastes, this is confirmed by the correlation coefficients for Freundlich isotherm that were greater than 0.9100 for both sugar cane and okra wastes for all the metal ions (Table 4) thus, representing a good fit of the observed data.

\section{Conclusion}

The above result showed that sugar cane waste also have the potential of removing $\mathrm{Pb}^{2+}, \mathrm{Ni}^{2+}$ and $\mathrm{Cd}^{2+}(\mathrm{qm}$ values). The similar order of removing the metal ion showed the similarity in structure, but other functional group (N-H) that provided charged site for binding, found in okra waste made it a better adsorbent. The Freundlich isotherm represented the adsorption process better than the Langmuir isotherm for the adsorbents judging by the good regression coefficient values $\left(R^{2}\right.$ above 0.9100$)$ for all metal ion both in the Sugar cane and Okra waste of the Freundlich isotherm model.

\section{Acknowledgement}

The authors acknowledge Yinka Omofoye for assisting in the experimental procedure and Mr Makinde Wasiu Oladotun of the Centre for Energy Research and Development, (CERD) OAU, in the metal analysis of the work. 


\section{References}

Akar, T., \& Tunal, S. (2005). Biosorption performance of Botrytis cinerea fungal by-products for removal of $C d(I I)$ and $\mathrm{Cu}(\mathrm{II})$ ions from aqueous solutions. Miner. Eng. 18, pp. 1099-1109. http://dx.doi.org/10.1016/j.mineng.2005.03.002

Al-Barak, A. B. S., \& El-Said, S. M. (2010). The Use of Some Food Industrial by Products for Waste Water $\begin{array}{llll}\text { Purification. Research Journal of Environmental Sciences, 4, 566-572. } & \text {. }\end{array}$ http://dx.doi.org/10.3923/rjes.2010.566.572

Al-Samawi, A. A., \& Hama, A. R. (2012). The Use of Okra as a Coagulant and Coagulant Aids in the Removal of Heavy Metals of Solid Waste Leachates. Eng. and Tech. Journal, 30(20).

Drake, L. R., Lin, S., Rayson, G. D., \& Jackson, P. J. (1996). Chemical modification and metal binding studies of Datura innoxia. Environ. Sci. Technol., 30(1), 110-114. http://dx.doi.org/10.1021/es950131d

Economic and Social Commission for Western Asia, ESCWA. (2003). Waste-water Treatment Technology: A General Review, United Nations. NewYork.

Fourest, E., \& Roux, J. C. (1992). Heavy metal biosorption by fungal mycelia by-products: Mechanism and influence of pH. Appl. Microbiol. Biotechnol. 37, pp. 399-403. http://dx.doi.org/10.1007/BF00211001

Gardea-Torresdey, J. L., Tiemann, K. J., Gonzalez, J. H., Henning, J. A., \& Townsend, M. S. (1996). Ability of silica-immobilized Medicago sativa (alfalfa) to remove copper ions from solution. J. Hazard. Mater. 48, pp. 181-190. http://dx.doi.org/10.1016/0304-3894(95)00155-7

Gupta, R., Ahuja, P., Khan, S., Saxena, R. K., \& Mohapatra, H. (2000). Microbial biosorbents: Meeting challenges of heavy metal pollution in aqueous solutions. Curr. Sci. India, pp. 967-973.

Hashem, M. A. (2007). Adsorption of lead ions from aqueous solution by okra wastes. International Journal of Physical Sciences, 2(7), 178-184.

Igwe, J. C., \& Abia, A. A. (2007). Equilibrium sorption isotherm studies of $\mathrm{Cd}(\mathrm{II}), \mathrm{Pb}(\mathrm{II})$ and $\mathrm{Zn}$ (II) ions detoxification from waste water using unmodified and EDTA-modified maize husk. Electronic Journal of Biotechnology, 10(4), 536-548. http://dx.doi.org/10.2225/vol10-issue4-fulltext-15

Kumar, U. (2006). Agricultural product and by -product as a low cost adsorbent for heavy metal removal from water and wastewater: A review. J. Sci. Res. Essay., 1(2), 33-37.

Nigam, P. S., Gupta, N., \& Anthwal, A. (2009). Pre-treatment of agro-industrial residues. In Nigam P. S., \& Pandey A. (Eds.), Biotechnology for Agro-Industrial Residues Utilization (pp. 13-33). Netherlands: Springer. http://dx.doi.org/10.1007/978-1-4020-9942-7

Oluyemi, E. A., Adeyemi, A. F., \& Olabanji, I. O. (2012). Removal of $\mathrm{Pb}^{2+}$ and $\mathrm{Cd}^{2+}$ ions from Wastewaters using Palm Kernel Shell CharcoaL (PKSC). Research Journal in Engineering and Applied Sciences, 1(5), 308-313.

Vohra, M. S. (2010). Adsorption of lead, ethylenediaminetetraacetic acid and leadethylenediaminetetraacetic acid complex onto granular activated carbon. Int. J. Environ. Sci. Tech., 7(4), 687-696. http://dx.doi.org/10.1007/BF03326178

Volesky, B. (1990). Biosorption and biosorbents. In B. Volesky (Ed.), Biosorption of Heavy Metals (pp. 3-6). CRC Press, Boca Raton, FL.

Volesky, B. (2007). Biosorption and me. Water Res. 41, pp. 4017-4029. http://dx.doi.org/10.1016/j.watres.2007.05.062

\section{Copyrights}

Copyright for this article is retained by the author(s), with first publication rights granted to the journal.

This is an open-access article distributed under the terms and conditions of the Creative Commons Attribution license (http://creativecommons.org/licenses/by/3.0/). 